http://doi.org/10.46754/gtc.2021.11.045

\title{
PROPOSED MARKETING STRATEGY FOR TOURISM USING VIRTUAL REALITY (VR) DURING COVID-19 (STUDY CASE: LABUAN BAJO)
}

\author{
Cindy Claudia Tamarin ${ }^{1}$, Neneng Nurlaela Arief $^{2} \&$ Agnesia Candra Sulyani $^{3}$ \\ 1,2,3 Institut Teknologi Bandung \\ (cindy_claudia@sbm-itb.ac.id, neneng.nurlalela@sbm-itb.ac.id, agnesia.c.sulyani@gmail.com)
}

\begin{abstract}
One of the factors in the development of culture and natural resources in Indonesia is the tourism sector. This is sought to help improve and improve the community's economy by opening employment opportunities and developing areas that have the potential as tourism hotspots, one of which is the Komodo National Park in Labuan Bajo. However, due to the outbreak of the SARS- COVID-19 virus, the government came up with a policy to stop economic activity in the tourism sector to prevent the spread of the virus by implementing Large-Scale Social Restrictions (PSBB). This paper aims to propose a tourism marketing strategy during the COVID-19 period by using Virtual Reality (VR) technology as a market research requirement for the TelkomGroup. This paper used a mix of methods to collect and test the data to prove the hypothesis including an External Analysis (PESTEL and Consumer Analysis) and Internal Analysis (STP or Segmentation, Targeting, Positioning and 4P Marketing Mix). The formulation of the business strategy used in this study was the Lean Canvas Business Model. Qualitative data was obtained from quantitative data analysis, which was in turn obtained by conducting interviews and collecting data surveys from a total of 360 respondents. The research resulted in a proposed marketing strategy for tourism for the COVID -19 period and beyond in the form of an STP and marketing mix, as well as its implementation through the introduction of VR. Therefore, by providing this recommendation, it is hoped that it can be a point of reference to promote and increase the interest of tourists again to support the "Pesona Indonesia" programme.
\end{abstract}

KEYWORDS: Covid-19, External and Internal Analysis, Labuan Bajo, Marketing Strategy for Tourism, Virtual Reality (VR)

\section{PURPOSE AND BACKGROUND}

The tourism sector in Indonesia has a lot of potential because it can affect the country's foreign exchange earnings. However, because of the COVID-19 virus, the government immediately made an emergency regulation with Guidelines for Large-Scale Social Restrictions activities by limiting direct social contact.

With the implementation of the health protocols, the tourism sector has started operating again. One of the tourist attractions that needs to be developed is the Komodo Tourism Park, Labuan Bajo, which is one of villages located in the Komodo sub-district, West Manggarai Regency, East Nusa Tenggara, Indonesia.

During the pandemic, it was difficult to predict how many tourists would visit the Komodo park in the future. This was due to the 'uncertainty' in each business sector caused by the pandemic. One solution that was considered is the use of Virtual Reality. Virtual Tourism has become a strategy for branding tourist destinations during the pandemic. Managers of tourism destinations in Labuan Bajo can work with hotel, restaurant, entertainment and other tourism stakeholders to collaborate with VR Tourism service providers. 


\section{METHODOLOGY}

The research methods that were used to collect data include both quantitative and qualitative methods with a descriptive analysis. The analysis used in this research paper to test the hypothesis include an External Analysis (PESTEL and Consumer Analysis) and an Internal (STP and 4P's Marketing Mix) with business/marketing strategy formulation using the Business Model Lean Canvas.

An interview method was used for qualitative research. The questionnaire was created using Google Forms and distributed online via email and social media. For the required number of samples, using the Slovin method.

\section{FINDINGS}

\section{Lean Canvas}

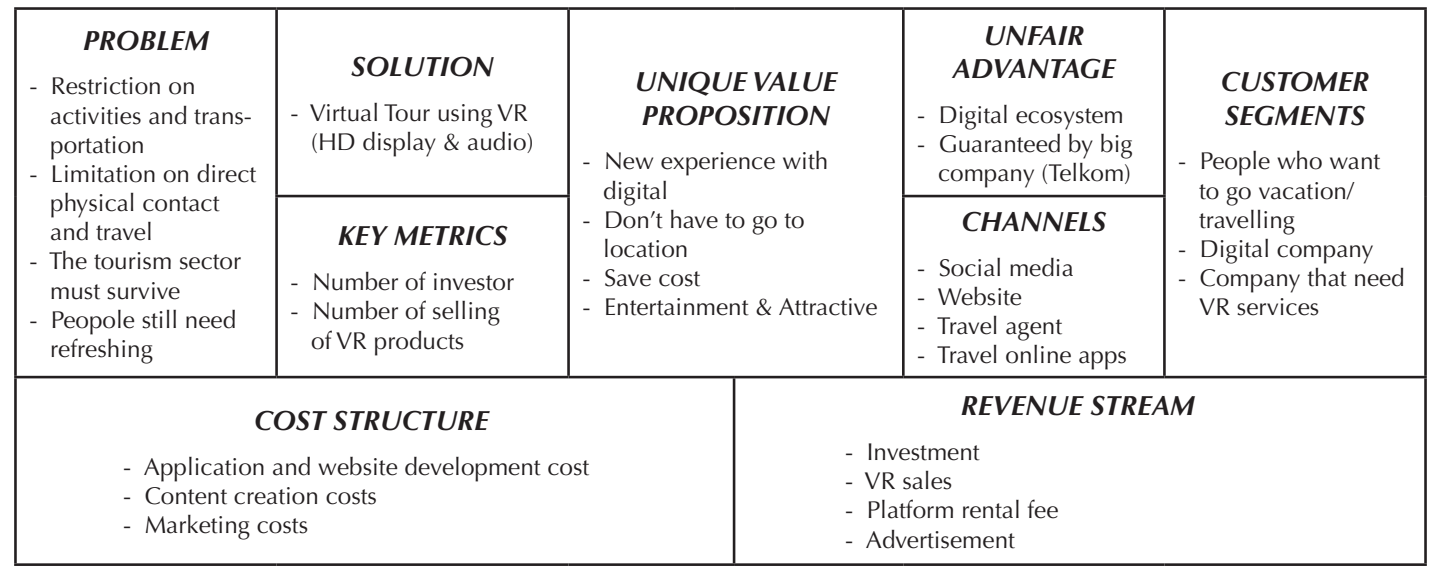

Figure 1: Lean Canvas

(Source: Processed Data)

\section{STP}

Segmenting: Differentiate customers (demographic, geographic, psychographic, and behaviour variables). Targeting: Evaluating the attractiveness of each segment and selecting the target segment.

Positioning: VR has a deeper point in fulfilling the desire of the users with a more real sensation.

Table 1: Suggested Market Target for Tourism using VR

\begin{tabular}{|c|c|c|}
\hline \multirow{5}{*}{ Demographic } & Gender & Male - Female \\
\hline & Age & 21 - 30 years old; 31 - 40 years old \\
\hline & Occupation & $\begin{array}{l}\text { Private Employee; BUMN/BUMD; Students; } \\
\text { Entrepreneur; Freelancer }\end{array}$ \\
\hline & Income & $\begin{array}{l}\text { Rp 1.000.000 - Rp. } 3.000 .000 \text { (middle) } \\
\text { Rp 3.000.001 - Rp. } 5.000 .000 \text { (middle-up) } \\
\text { Rp 5.000.001 - Rp. } 10.000 .000 \text { (up) }\end{array}$ \\
\hline & Status Social & All \\
\hline \multirow{3}{*}{ Geographic } & Country & Indonesia \\
\hline & Region & Java \& Sumatra Island \\
\hline & Density & Urban; Sub-Urban; Rural \\
\hline Psychographic & Interest & $\begin{array}{l}\text { Playing Game; Watching Movie; Education } \\
\text { Learning; Traveling }\end{array}$ \\
\hline
\end{tabular}




\begin{tabular}{ll}
\hline \multirow{2}{*}{ Behaviour } & $\begin{array}{l}\text { Social Media; Family/Friends; Search Engine; Travel } \\
\text { Online Application; TV/Radio }\end{array}$ \\
\cline { 2 - 3 } & $\begin{array}{l}\text { Know about VR and have interested in using the } \\
\text { product }\end{array}$ \\
\hline
\end{tabular}

(Source: Processed Data)

4P's Marketing Mix

Products: 360 virtual images and VR Glasses.

Price: Free or service/rental fees per hour.

Place: Create a spot to try and taking virtual tours through online meeting.

Promotion: Digital marketing.

\section{CONCLUSION}

Due to the COVID-19 pandemic, the tourism sector has been temporarily suspended because it has to follow government regulations to ensure public health and safety. Therefore, in order for it to start moving again it must follow all of the applicable health regulations and procedures. Since access to travel is still limited, one way to restore the tourism industry is through the use of technology such as Virtual Reality. By switching to a digital system, people can enjoy an easy and close vacation from the comfort of their own homes.

\section{CONTRIBUTION/PRACTICAL IMPLICATIONS}

The author suggests a cooperation with SmartEye because there are many facilities that will help Telkom to prepare the groundwork for VR and AR technology. The benefits include more VR technology education, getting partners and resources who are ready to collaborate and that already have a platform in the form of a website. This will also affect consumer interest in being able to visit Komodo National Park in Labuan Bajo after the COVID-19 pandemic having experienced it in Virtual Reality.

\section{REFERENCES}

Aurya, A. (2012). Running lean: Iterate from Plan A to A Plan that works (2nd ed.). Sebastopol, California: O'Reilly.

Kotler, Philip \& Kevin, L. K. (2016). Marketing management (15th ed.). England: Pearson Education Limited. Sherman, W. R., \& Alan, B. C. (2003). Understanding virtual reality interface, application, and design. USA: Elsevier Science. 